\title{
Przestrzenie lokalnej demokracji. Szkic z gdańskiej perspektywy
}

\author{
Spaces of local democracy: A sketch from the Gdańsk perspective

\section{Abstract}

This article is an expression of thinking about the spaces of local democracy, which was based on the research project "Gdańsk as a Shared Place" (2014-2015). Due to the fact that the theses and results of this 'old' project are updated in the light of the deepening crisis of the social in the pandemic conditions, I present in the article the content selected from the research report, hopefully emphasizing their importance in shaping various, sometimes surprising forms and places of democracy. I am doing this, counting on the fruitful expansion of the field of understanding and practicing bond-forming, communal forms of social life. Thus, I follow the path that Professor Stanisław Kawula (1939-2014) pioneered in social pedagogy, tirelessly describing the social condition and - thus - updating the dimensions of democracy in various perspectives [for example, in relation to the diagnosed risks (2003; 2005 etc.)]. Hence, I dedicate this text to him, and choosing the horizon of local experience, I want to draw attention to the meaning of research descriptions of this local dimension, which is especially important today, in a social crisis condition. I conclude with a reflection on the meanings of non-consensual democracy, inscribed in urbanity as a way of social life, and emphasize the importance of a neighborhood which - literally: having a place locates democracy in a special way. Such a location allows us to capture its essential meanings and show the democratic productivity of everyday, neighborly production of commonality, that is the common good, constantly crumble and constantly arouse mutual attention and ask for care.

\section{Keywords}

city, democracy, local community, commonality, space

Pamięci Profesora Stanisława Kawuli, który w roku 2021 obchodzilby 50-lecie swojego doktoratu, $z$ nieustającym podziękowaniem

In memory of Professor Stanisław Kawula, who would be celebrating the $50^{\text {th }}$ anniversary of his doctorate in 2021 , with endless thanks 


\section{Projekt „Wspólny Pokój Gdańsk”}

„Wspólny Pokój Gdańsk” to - realizowany w latach 2013-2015 i skupiający ponad dwudziestoosobową grupę badaczy - projekt Gdańskiego Towarzystwa Naukowego, współpracującego przy jego realizacji z Uniwersytetem Gdańskim, Akademią Sztuk Pięknych w Gdańsku oraz Muzeum Historycznym Miasta Gdańska' ${ }^{1}$

Zamysł projektu powstał w związku z uwarunkowaniami życia w miastach, które - z jednej strony - są wyrazem wzrastającego znaczenia terytorium dla jednostek i grup („,w zalewie szczegółów, związanych z wszystkimi możliwymi miejscami na świecie, zaczyna nas obchodzić coraz częściej właściwie tylko szczegół miejsca własnego. To redukcja mozaiki do elementu, holograficzna koncentracja świata do jednego punktu na mapie"2). Z drugiej strony, miasta - coraz bardziej globalne i rozumujące w kategoriach makrospołecznych - stają się „odczłowieczone”, choć przypominają węzły gordyjskie problemów społecznych, których nie sposób rozwiązać3. Nie wspiera ich rozwiązywania aktualna orientacja na rynek i przedsiębiorczość, wszechobecna - niestety - w politykach i programach pomocy oraz integracji spolecznej. ${ }^{4}$. W związku z tym w projekcie realizowano cele w zakresie kształtowania nowej miejskości; podmiotowej kondycji życia w mieście, odbudowującej wspólnotowe więzi i kształtującej przestrzeń, w której ważny jest człowiek, a nie jedynie wolny rynek; przestrzeń głęboko humanistyczną, wrażliwą na człowieka. Nieodłączne w tym było założenie, że nieunikniony jest schyłek dominującego przez lata, a obracającego się przeciw człowiekowi, neoliberalnego paradygmatu i zarazem zorientowanego na wartości rynkowe formatu życia społecznego. Projekt, złożony jako oferta realizacji zadań publicznych Gdańska, zakładał też, że gdańska nowa miejskość będzie miała obywatelski charakter, osiągany w przestrzeni miasta jak przestrzeni wspólnego pokoju; kształtowanej na rozwiązaniach edukacyjnych ugruntowanych w badaniach i składających się na specyficznie miejską wersję edukacji. Edukacji, która atutem miasta czyniłaby jego kulturowe zróżnicowanie ${ }^{5}$.

Badania dające grunt takiej edukacji zostały zrealizowane i są raportowane w książce Miasto jak wspólny pokój. Gdańskie modi co-vivendi ${ }^{6}$. W tej wypowiedzi

${ }^{1}$ Projekt dofinansowany ze środków Miasta Gdańska, umowa nr: RWB-W/1299/BPK/90/U-W. BIEŻ./2014/MM z dnia 14 marca 2014 roku. Oceniony jako innowacyjny i najlepszy w roku otrzymał Honorową Nagrodę Gdańskiego Towarzystwa Przyjaciół Sztuki za rok 2015.

2 T. Szkudlarek, Miejsce, przemieszczenie, tożsamość, [w:] J.P. Hudzik, J. Mizińska (red.), Pamięć, miejsce, obecność. Wspótczesne refleksje nad kultura i ich implikacje pedagogiczne, Lublin 1997, s. 152.

${ }^{3}$ S. Sassen, Globalizacja. Eseje o nowej mobilności ludzi i pieniędzy, przedmowa K.A. Appiah, przekł. J. Tegnerowicz, Kraków 2007.

${ }^{4}$ M. Mendel, B. Skrzypczak (red.), Praca socjalna jako edukacja ku zmianie, Warszawa 2013.

${ }^{5}$ Z. Bauman, O edukacji, przekł. P. Poniatowska, Wrocław 2012.

${ }^{6}$ M. Mendel (red.), Miasto jak wspólny pokój. Gdańskie modi co-vivendi, Gdańsk 2015. Z książki tej pochodzą liczne fragmenty moich analiz wykorzystane w tym tekście. Ugruntowują one tytułową 
chciałabym zwrócić uwagę na - ustalone w ich wyniku - przestrzenie, w których możliwe stawało się wzajemne „układanie się" i współtworzenie przez mieszkańców akceptowalnego przez nich ładu; to przestrzenie demokracji lokalnej.

Najpierw kilka słów o pojęciach orientujących w języku tego badania.

\section{Miasto jak wspólny pokój}

Wspólny pokój jest najbardziej nośną w koncepcji teoretycznej i kluczową dla całego projektu metaforą, zaczerpniętą z filozofii Jacques’a Rancière’a. Kierunek myśli filozofa najlepiej wyrażają jego słowa, kiedy pisze o sobie, że zajmuje się „,czasem i przestrzenią jako formami konfiguracji naszego "miejsca " w społeczeństwie" Natomiast pisząc o „postrzegalnym” (sensible), kategorii pozwalającej wyrażać jedynie to, co zmysłowe (sensual) i jednocześnie mające sens („sensowne”), Rancière wiąże ją z takim mieszczeniem się ludzi w przestrzeni ich życia, które byłoby wspólnie odczuwanym i akceptowanym ładem, na który ludzie się zgadzają, bo widzą, słyszą i czują, że jest sensowny, a dzięki temu też zapewniający im godność. Dzieleniem postrzegalnego filozof ten nazywa

system odczuwalnych (sensible) pewników, które jednocześnie uwidaczniają istnienie tego, co wspólne, i podziałów, definiujących jego poszczególne miejsca oraz części. Dzielenie postrzegalnego ustanawia jednocześnie to, co jest współdzielone, i jego odrębne części. Owo rozmieszczenie części i miejsc opiera się na dzieleniu - przestrzeni, czasu i form aktywności - które określa, w jaki sposób możliwy jest udział w tym, co wspólne, i jak te wszystkie elementy uczestniczą w samym procesie dzielenia ${ }^{8}$.

Jest więc to ład idealny. Dopiero wtedy, gdy uda się ludziom osiągnąć takie mieszczenie się w - zawsze wspólnej przecież - rzeczywistości; mieszczenie będące dla nich porządkiem, który „widać, słychać i czuć” i na który się zgadzają, bo jest sensowny, a przez to też godny - dopiero wtedy można, nawiązując do pluralistycznego agonizmu Chantal Mouffe, mówić o walce, która będzie ścieraniem się przeciwników, a nie unicestwianiem się wzajemnym przez wrogów 9 . Wówczas też można pełniej zrozumieć demokrację jako płaszczyznę spotkania, warunek możli-

refleksję o „przestrzeniach demokracji lokalnej”. Zob. M. Mendel, Wspólny Pokój Gdańsk. Miejskie „modi co-vivendi” w badaniu metoda Krytycznej Historii Miasta, [w:] eadem (red.), Miasto jak wspólny pokój. Gdańskie modi co-vivendi, Gdańsk 2015.

7 J. Rancière, Dzielenie postrzegalnego. Estetyka i polityka, przekł. M. Kropiwnicki, J. Sowa, wstęp M. Pustoła, słownik zestawił K. Mikurda, Kraków 2007, s. 38.

${ }^{8}$ Ibidem, s. 69.

${ }^{9}$ C. Mouffe, Paradoks demokracji, przekł. W. Jach, M. Kamińska, A. Orzechowski, Wrocław 2005. 
wości rozmowy przeciwników, jak widziała ją Mouffe. U Jacques’a Ranciere’a znajduje to swój wyraz explicite: „(d)emokracja jest wspólnotą dzielenia w podwójnym znaczeniu tego słowa: przynależności do wspólnego świata, który da się wyartykułować jedynie w polemice, oraz zebraniem, do którego nie może dojść inaczej, niż poprzez walkę"10.

Teorię Rancière’a można więc rozumieć jako myśl owocującą możliwościami „podzielania”, a nie „dzielenia świata”, współmieszczenia się w jego przestrzeni i czynienia go w ten sposób naprawdę wspólnym, to znaczy wolnym nie od różnic, ale od podziałów.

Wydaje się, że doskonale tę myśl i - w szczególności - obecny w niej problem równości i sprawiedliwości społecznej wyraża porównanie do współzamieszkiwania w jednym pokoju. Równość, sprawiedliwość społeczna są tu założeniem, a nie celem, końcowym rezultatem działań, które podejmujemy. Przyjąwszy, że jesteśmy równi, żyjemy, tworząc świat sprawiedliwy. Założenie to sprawia, że współmieszkańcy układają się ze sobą na co dzień, nie rujnując swojego poczucia sprawiedliwości, kiedy z poszczególnych elementów przestrzeni w danym momencie korzysta jeden, a nie jednocześnie obaj lokatorzy. Użytkownicy miasta, niezależnie od swojej kulturowej proweniencji i społecznego statusu mogą podobnie układać się ze sobą, współdzieląc miejską przestrzeń i - jak współlokatorzy w jednym pokoju - czynić ją własną, pozostając w kontakcie i gotowości do zmian miejsca dokonywanych z uwzględnieniem potrzeb innych ludzi - dzielenia się miejscem; jego ustępowania jako czynienia go dostępnym dla Innego itd.

\section{Modi co-vivendi w projekcie „Wspólny Pokój Gdańsk”}

Przedstawione tu myślenie o wspólnym pokoju prostą drogą prowadzi do refleksji o modus co-vivendi oraz rozmaitych modi co-vivendi jako sposobach ujmowania społecznie podzielanego życia (współżycia), którego postaci są wzajemnie akceptowane, prowadząc nie tylko do poczucia, że „tak da się razem żyć”, ale że „tak da się razem żyć dobrze".

Pierwsze centrum zainteresowania, modus vivendi, to - w słownikowej wersji - „sposób ułożenia wzajemnych stosunków umożliwiający współżycie ludzi o odmiennych poglądach lub interesach", a także umowa (na przykład międzynarodowa) „o charakterze tymczasowym, zawierana z myślą o ostatecznym uregulowaniu wzajemnych stosunków w okresie późniejszym" ${ }^{11}$. Innymi słowy - sposób „dogadania się”, umożliwiający współżycie mimo komplikujących je różnic. Bez-

\footnotetext{
10 Cytuję za: K. Mikurda, Słownik [w:] J. Rancière, Dzielenie postrzegalnego..., op. cit., s. 178.

11 http://sjp.pwn.pl/slownik/2568210/modus_vivendi [dostęp: 2.05.2021].
} 
pośrednio w obszar badawczego zainteresowania tego rodzaju co modus vivendi, lecz dalece stabilniejszym układaniem się mieszkańców miast wprowadza kategoria modus co-vivendi opisana przez Zygmunta Baumana. To ona stała się sednem poszukiwań badawczych w projekcie „Wspólny Pokój Gdańsk”. Bauman pisał:

W naszym społeczeństwie coraz bardziej widoczne są diaspory i nie ma nic dziwnego w tym, że nasila się podejrzliwość oraz lęk mieszkańców miast w kontaktach nie tylko po prostu z obcymi (życie w mieście zawsze bowiem oznaczało życie wśród obcych), ale z nowym, niespotykanym wcześniej rodzajem obcych, a zatem obcych »nieudomowionych « $\mathrm{i}$ "nieoswojonych «, niosących nieznane zagrożenia. Pierwszą "naturalną" reakcją jest wycofanie się do miniaturowych twierdz znanych jako »osiedla zamknięte« i szczelnie zaryglowane drzwi; bezzwłocznie po tym następuje żądanie usunięcia obcych, a wtedy na scenę wkraczają różnej maści demagodzy. Jeśli nie podejmie się działań zaradczych, proces ten nabierze tempa i wypadki zaczną toczyć się lawinowo: strach sprawia, że ludzie nie kontaktują się i nie porozumiewają się z tymi, których uważają za źródło zagrożenia, a gdy zawodzi komunikacja, widmo rzeczywistego, czy rzekomego niebezpieczeństwa staje się bardziej wyraziste, co z kolei pogłębia zapaść komunikacyjną tak, że wszelkie kontakty ostatecznie ustają. Gdy zaś zanika wzajemny kontakt, niewielkie są szanse na zweryfikowanie wyobrażeń w praktyce i niemal żadne na wypracowanie wzajemnie satysfakcjonującego modus co-vivendi, w którym kulturowe zróżnicowanie miasta, obecnie postrzegane jako wada, stałoby się jego atutem. Myślę, że edukacja może zrobić całkiem sporo dla przecięcia tego węzła gordyjskiego [wyróżnienie - M.M. $]^{12}$.

Podobne zdanie o potrzebie wypracowywania modus co-vivendi można znaleźć w innej książce Zygmunta Baumana, w rozdziale pod prowokacyjnym tytułem: Obcy sa niebezpieczni. Czy rzeczywiście ${ }^{13}$. Nieco inaczej, ale również w interesującej tu perspektywie, Autor wcześniej, w Płynnym życiu, pisał o modi co-vivendi w kontekście opisu syndromu konsumenckiego i panowania rynku, który „pośredniczy dzisiaj w nawiązywaniu i zrywaniu więzi międzyludzkich” i wpływa na wszelkie relacje zarówno w sferze prywatnej, jak publicznej ${ }^{14}$. Rynek - według Baumana - opisując życie jako ciąg "rozwiązywalnych” problemów, oferuje możliwe do nabycia środki, urządzenia i usługi, „bez których dla coraz większej liczby ludzi pozbawionych umiejętności społecznych życie-w-społeczeństwie, współżycie-z-innymi, 'odnoszenie się, do innych oraz wypracowywanie i pielęgnowanie modi co-vivendi okazałoby się zadaniem karkołomnym, niepojętym i niewykonalnym"15. W tych warunkach obserwujemy zanik przestrzeni publicznej, a „najcenniejszą umiejętnością, dającą realną szansę [jej] wskrzeszenia (...) jest dziś umiejętność

12 Z. Bauman, O edukacji, op. cit., s. 111-112.

13 Z. Bauman, Collateral Damage. Social Inequalities in a Global Age, Cambridge-Malden 2011. W oryginale: Strangers are dangers. Are they indeed?

14 Z. Bauman, Płynne życie, przekł. T. Kunz, Kraków 2007, s. 138.

15 Ibidem, s. 139. 
porozumiewania się z innymi: prowadzenia dialogu, negocjowania, wzajemnego poznawania swoich racji i rozwiązywania konfliktów będących nieodłącznym elementem współżycia społecznego" ${ }^{16}$. Edukacja przysposabiająca do tego rodzaju kompetencji jawi się zatem znowu jako nadzieja, że lepszy świat jest rzeczywiście możliwy, przy czym „coraz pilniejszą potrzebą staje się nieustanna i wciąż usprawniana edukacja o b y w a t e $1 \mathrm{~s} \mathrm{k}$ a"17. Powinna to być edukacja trwająca przez całe życie, ale - inaczej niż gorący w neoliberalnej rzeczywistości polityczny postulat lifelong learning - nie powinna wiązać się $\mathrm{z}$,dostosowywaniem naszych umiejętności do szybkiego tempa zmian zachodzących w świecie, ale z czynieniem owego szybko zmieniającego się świata przestrzenią bardziej gościnną dla człowieka"18.

Zgadzając się z tym zdaniem, edukacyjnie zorientowałam myślenie o mieście „bliskim sercu” i „gościnnym” jak wspólny pokój, a przyjęte w nim założenie równości w praktykowaniu podzielania przestrzeni przeniosłam w szersze ramy refleksji dedykowanej modi co-vivendi. Stanowczo wyrażanym tu w liczbie mnogiej (nie pojedynczo: modus, a modi), bo wzajemnie satysfakcjonujące sposoby współżycia są nie jednym, a zawsze wieloma rozwiązaniami, akceptowalnymi w wielorakich i licznych środowiskach naszego życia ${ }^{19}$. O ich wielorakości i dynamicznych zmianach, charakterystycznych dla ponowoczesnej kondycji życia społecznego, tworząc ważny kontekst dla tego stanowiska, pisze między innymi Gianni Vattimo (puentujący swoje o tym rozważania tezą o paradoksie transparentności w społeczeństwie, w którym w imię wolności i autonomii, w warunkach demokratycznie słyszalnej artykulacji roszczeń wielu różnorodnych grup, każda domaga się jawności w działaniach grup pozostałych, potęgując tym samym kryzys zaufania i produkując ograniczenia upragnionej wolności i autonomii) ${ }^{20}$. W tym samym kierunku idą wypowiedzi autorów opisu - charakteryzującej dzisiejszy brak bezpieczeństwa i zaufania - a mianowicie w stronę refleksyjnej modernizacji (wśród nich głównie Ulrich Beck ${ }^{21}$ ). Niedawno w swojej głośnej książce In Mistrust We Trust. Can Democracy Survive When We Don't Trust Our Leaders? wyzwanie ujęcia warunków rozwoju topniejącego zaufania podjął Ivan Krastev, głosząc, że „przejrzystość zabija demokrację"22. Zygmunt Bauman w Płynnej nowoczesności nadaje tej różnorodności, skutkującej kryzysem zaufania, kluczowe znaczenie w opisie współczesnej

16 Ibidem, s. 198.

17 Ibidem, s. 199.

18 Ibidem, s. 198.

19 W tekstach Heleny Radlińskiej, reprezentującej dzisiejszą klasykę polskiej pedagogiki społecznej, środowisko życia często wyrażane jest w liczbie mnogiej, z akcentem na jego jednostkowość. Zob. H. Radlińska, Pedagogika społeczna, Warszawa 1961.

${ }^{20}$ G. Vattimo, Społeczeństwo przejrzyste, przekł. M. Kamińska, Wrocław 2006.

21 U. Beck, A. Giddens, S. Lash, Modernizacja refleksyjna, przekł. J. Konieczny, Warszawa 2009.

22 Zob. wywiad z Ivanem Krastevem, w którym przedstawia on swoje tezy, między innymi te zawarte we wspomnianej książce: Krastev: Walka o przejrzystość zabija demokrację, http://www.kry- 
rzeczywistości i uzasadnia, że wszystko dzisiaj, na kształt płynów, nie ma trwałej formy, a jedynie przejściowe, które - jak naczynia - utrzymują formę (na przykład określone podmiotowości, reprezentacje, tożsamości) jedynie tymczasowo, do momentu przelania cieczy do innego naczynia ${ }^{23}$. Na tego rodzaju podstawach sformułowałam założenie o pluralnej istocie modi co-vivendi $\mathrm{i}$ - w konsekwencji zorientowałam badawcze poszukiwania $\mathrm{w}$ projekcie na równoległe funkcjonowanie wielu zróżnicowanych modi co-vivendi, zarówno w jednym miejscu - w tym wypadku w Gdańsku - jak też często w jednym czasie (na przykład w rzeczywistości po II wojnie światowej, eksplorowanej przez kilkoro z badaczy).

Modi co-vivendi miast, rozumiane jako w różnym czasie i miejscu, wzajemnie satysfakcjonujące, różnorakie sposoby czynienia atutu z kulturowego zróżnicowania zurbanizowanych przestrzeni, stanowily w projekcie cel badań zorientowanych wdrożeniowo - animacyjnie i edukacyjnie. Dzięki nim powstały - z jednej strony - naukowe opisy, konceptualizacje takich wzorów układania się ze sobą mieszkańców miast, które mają dla nich sens i stanowią wartość. W książce Miasto jak wspólny pokój... zamieszczono te opisy, przedstawiając wyniki dwudziestu szczegółowych badań, zrealizowanych w zespole badawczym projektu. Z drugiej zaś strony badania te dały początek dalszym projektom, odwołującym się do ukształtowanej na ich podstawie wiedzy o edukacji i animacji w procesie tworzenia miasta, do którego jego mieszkańcy mają prawo i w którym zachowują swoje prawa; miasta „bliskiego sercu jego mieszkańców”24, czyli miasta stanowiącego przestrzeń ich podmiotowej, przy tym także obywatelskiej, aktywności. Rozwija się ona dzisiaj $w$ formach i miejscach nowych, między innymi dosłownie pomiędzy - charakterystycznymi dla wielkich miast - enklawami biedy i bogactwa ${ }^{25}$. Wśród wspomnianych projektów znajdują się działania edukacyjne i animacyjne wrażliwe na te formy i te miejsca, na przykład ogólnodostępny kurs „Badacz i animator miejskiej przestrzeni - BAMP"26.

tykapolityczna.pl/artykuly/ue/20130331/krastev-walka-o-przejrzystosc-zabija-demokracje [dostęp: 2.05.2021].

${ }^{23}$ Z. Bauman, Płynna nowoczesność, przekł. T. Kunz, Kraków 2006.

${ }^{24}$ D. Harvey, Bunt miast. Prawo do miasta i miejska rewolucja, Warszawa 2012.

${ }^{25}$ M. Mendel, Pedagogika miejsca wspólnego. Miasto i szkoła, Gdańsk 2017.

${ }^{26}$ To trzydziestogodzinny kurs oferowany przez Gdańskie Towarzystwo Naukowe, wpisujący się w miejską politykę i strategię uczenia się przez całe życie (zgodnie z systemem Krajowych Ram Kwalifikacji i ECTS). Pierwsza edycja, wpisana w projekt „Wspólny Pokój Gdańsk”, została zrealizowana w 2014 roku pod kierownictwem Marcina Boryczko. Objęła 11 osób - pracowników socjalnych, pedagogów społecznych i innych - działających animacyjnie w swoich środowiskach i „kaskadowo”, mniej lub bardziej formalnie, upowszechniających wiedzę i doświadczenie ukształtowane przez uczestnictwo w kursie BAMP, wśród innych mieszkańców miasta, potencjalnych liderów lokalnych społeczności. 


\section{Przestrzenie gdańskiej demokracji w świetle wyników badań}

Podaję dalej kilka przykładów zaczerpniętych z badań nad miejskimi modi co-vivendi, zrealizowanych w ramach projektu „Wspólny Pokój Gdańsk” i raportowanych we wspomnianej książce ${ }^{27}$. Wydaje się, że mogą one dać wyobrażenie zarówno o rozległości obszaru myślenia o przestrzeniach demokracji w mieście (o tym, jak mogą one być pomyślane, jakie mogą być ich koncepcje, gdzie - w sensie teoretycznej, prospektywnie zorientowanej refleksji - można ich szukać etc.), jak i nieskończoności postaci, form, w których demokratyczna wspólność znajduje swoje przejawy (czyli o tym, jak przestrzenie demokracji mogą być praktykowane).

\section{Przestrzeń drogi (czyli o demokratycznej mocy wędrowania)}

Etnograf miejskich wędrówek, Lesław Michałowski, zrealizował swoje badanie, spacerując z gromadami ich uczestników i osiągając efekt wspólnie „wychodzonej” diagnozy poszczególnych miejsc co do ich cech, takich jak wiarygodność, przyjazność, czyli Baumanowska uprzejmość, określająca autentyczność miejskich przestrzeni. Powstające w ten sposób rejestry miejsc to - dokonywane w drodze, metodą wzajemnego ożywiania pamięci i wizualnego „konsumowania” elementów przestrzeni - wspólne wypracowywanie akceptowalnego wzoru bycia i w szczególności bycia ze sobą w mieście. Badanie Michałowskiego okazało się badaniem autentyczności miasta jako istotnego warunku miejskich modi co-vivendi. Jego wyniki można traktować jak opis cech przestrzeni, która - naznaczona szlakami wędrówek - staje się zbiorem miejsc nie tylko dobrze rozpoznanych i przez to oswojonych, bezpiecznych, jak pisze o miejscach Yi-Fu Tuan ${ }^{28}$. To przestrzeń głęboko humanistyczna, bliska sercu - używając języka Davida Harveya - bo złożona z miejsc odczytanych jako życzliwe ich użytkownikom, takie, w których nie tyle „da się żyć”, ile da się żyć godnie. Przesuwa to myślenie o co-vivendi w stronę refleksji o sile słabego podmiotu; o emancypacyjnej - i upodmiotawiającej „Zwykłych" mieszkańców - roli wędrowania po mieście. Jak widział ją Michel de Certeau, stanowi ona jedną z dwóch taktyk przezwyciężania strategii jako odgórnie konstruowanych rozwiązań, przestrzennie formatujących życie w mieście ${ }^{29}$. Stanowi je wędrowanie i opowiadanie mieszkańców oraz użytkowników miasta.

Z kolei Dorota Jaworska i Khedi Alieva opisują gdańskie modi co-vivendi jako rozmaite sposoby, w jakie - przy braku wspólnego języka, w szczególności kultu-

\footnotetext{
${ }^{27}$ M. Mendel (red.), Miasto jak wspólny pokój..., op. cit.

28 Y.-F. Tuan, Przestrzeń i miejsce, przekł. A. Morawińska, Warszawa 1987.

29 M. de Certeau, Wynaleźć codzienność. Sztuki działania, przekł. K. Thiel-Jańczuk, Kraków 2008.
} 
rowego - dochodzi się do porozumienia. To rodzaj współżycia opartego na skutecznej komunikacji, bez której nie ma możliwości osiągnięcia go we wzajemnie satysfakcjonującej postaci. Miejskie modi co-vivendi "na styku z imigrantami” próbującymi osiąść w Gdańsku stabilizują się w drodze, która okazuje się także dla jednych - drogą do nowego życia w nowym miejscu, dla drugich - dojściem do nowych znaczeń miejsca własnego, dosłownym otwarciem swojego miasta jak zamkniętej dotąd koperty czasoprzestrzeni ${ }^{30}$. Co-vivendi w badaniach Jaworskiej i Alievej wydaje się drogą, nigdy nie statycznym porozumieniem, które zawsze właśnie się staje i tak kształtuje swój dynamiczny status.

\section{Przestrzeń performatywna (czyli miasto obywatelskie jako teatr)}

Marcin Boryczko, relacjonując badanie przeprowadzone wśród gdańskich rekonstrukcjonistów, przedstawia praktyki odgrywania scen z przeszłości w zurbanizowanej przestrzeni i pokazuje je jako sposób na akceptowalne współbycie w niej, wersję miejskiego co-vivendi (możliwe, że głównie dzięki dokonującym się wskutek odgrywania rekonfiguracjom, między innymi ideologii narodowych itp.). Forma ta znosi podziały i pozwala żyć $\mathrm{z}$ poczuciem wzajemnej akceptacji i pełnego życzliwości zainteresowania innymi, niezależnie od ich historycznie ukształtowanego statusu, dawnej i aktualnej pozycji czy innych postaci rekonstruowanej, choć nie petryfikowanej, a raczej negocjowanej „na gorąco, tu i teraz” przynależności kulturowej i społeczno-politycznej. Analizowane w badaniu Marcina Boryczko odgrywanie jest społecznie znaczącym, więziotwórczym wędrowaniem. Wędrowaniem aktualnym, które lokując się w opowieści o przeszłości i w rozmaitych miejscach miasta zarazem, stanowi niewątpliwie jedno $\mathrm{z}$ dzisiejszych, miejskich modi co-vivendi. Wędrowaniem performatywnie sprawczym, jak sprawcze jest gromadzenie się i robienie czegoś razem; zgromadzenie, które przedstawia obywatelskie artykulacje i - jak głosi performatywna teoria zgromadzeń Judith Butler w sensie demokratycznym mówi nawet wtedy, kiedy milczy ${ }^{31}$.

\section{Przestrzeń konfliktu}

Dominik Krzymiński wskazuje na konflikt jako kryterium formowania przestrzeni lokalnej demokracji, czyniąc to w swojej badawczej wędrówce po subiektywnie wybranych miejscach, leżących na postoczniowych terenach Gdańska. Miejsc tych albo już nie ma, albo stanowią stoczniowy element w nowo konstruowanym krajobrazie. Autor pokazuje społeczne działania wokół nich, zarejestrowane w dwóch

30 D. Massey, Space, Place and Gender, Cambridge 1994.

${ }^{31}$ J. Butler, Zapiski o performatywnej teorii zgromadzeń, przekł. J. Bednarek, Warszawa 2016, s. 19. 
wybranych latach (2012-2014), ale rozpinające się w dużo szerszej przestrzeni czasowej z powodu konfliktów, które wywołują lub na które są reakcją. Krzymińskiego opis gdańskich modi co-vivendi zawiera się - dosłownie i w przenośni pomiędzy tymi konfliktami, w pograniczności ich rozwiązywania - jak sugeruje Autor za Chantal Mouffe - drogą przechodzenia od antagonizmu do agonizmu, kiedy istnieją warunki dla ścierania się stojących twarzą w twarz przeciwników, a nie walczących na śmierć i życie wrogów. Obrońcy stoczni i inni aktorzy grający na scenie zarysowanej w badaniu w swoich licznych starciach układają się pomiędzy sobą, tworząc w powstałych nie-miejscach albo wokół nich - miejsc tracących znaczenia, mniej lub bardziej intencjonalnie $\mathrm{z}$ nich wypróżnianych ${ }^{32}$ - warunki agonistycznego pluralizmu i dialogującą wspólnotę, w której cechą więzi jest podzielana wrażliwość na miejsce. Heideggerowska troska (sorge, cura), jako postać Dasein, jaźni czułej na współbytujące, stanowiące z nią jednię otoczenie, wydaje się znajdować w niej swój wyraz ${ }^{33}$. Troska, odnosząca się do miejsca, zdaje się działać tu jak spoiwo i być warunkiem osiągania co-vivendi w mieście topniejących znaczeń miejsc.

\section{Przestrzeń sąsiedzka}

Na sąsiadowanie jako przestrzeń demokracji lokalnej wskazała m.in. Dorota Rancew-Sikora, prowadząc analizę powojennego mieszkalnictwa. Na tym tle ukazuje między innymi przeróbki mieszkań, połączone z wydzielaniem przedpokoju, pozwalającego na stworzenie odrębnych układów mieszkaniowych. Przeróbki te są wyrazem miejskich kreacji, niezwykle płodnych ze względu na co-vivendi. Zabiegiem, który pozwala Badaczce na krytyczną rekonstrukcję przestrzennych uwarunkowań rozmaitych modi wspólnego życia mieszkańców starych, gdańskich mieszkań, podzielonych na nowo w powojniu, jest sprowadzenie analiz na poziom mikrorelacji międzyludzkich, „widocznych” w dokonywanych przez nich przekształceniach (jak zauważa Badaczka, tak powstaje wiedza nieformalna o mieście i jego mieszkańcach, ceniona szczególnie w świetle aktualnej dominacji formalnej wiedzy o nim, na przykład wiedzy historycznej). Podzielona na nowo przestrzeń niesie ponadto nowe znaczenia, coś umożliwia, ale i w czymś przeszkadza itd. Autorka odczytuje to, traktując rysunkowe schematy mieszkań albo biograficzne opowieści czy filmy o zamieszkiwaniu powojennych miast, jako zakodowane w nich modi co-vivendi. Każdy taki schemat albo opowieść to pewien wynik układania się ze sobą mieszkańców dzielonych mieszkań; z jednej strony to reprezentacja

32 M. Augé, Nie-miejsca. Wprowadzenie do antropologii hipernowoczesności, przekł. R. Chymkowski, Warszawa 2010.

33 M. Heidegger, Bycie i czas, przekł. B. Baran, Warszawa 2013. 
społecznych mikropraktyk repartycji, polegających na władzy dzielenia przestrzeni i panowania zarówno nad nią, jak i jej mieszkańcami; z drugiej zaś polega na podzielaniu tej przestrzeni, będącym wyrazem wrażliwości na obecność i potrzeby współmieszkańców. Gdzieś, wśród tych skrajnych podejść, lokuje się co-vivendi, osiągnięte jako akceptowalne wersje bycia razem i osobno we współdzielonej przestrzeni. W badaniach Rancew-Sikory - dosłownie i w przenośni - ukazują się one oczom, widoczne w analizowanych przez Autorkę planach mieszkań, barwnych, biograficznych narracjach i opisach filmowych scen, przywołujących obrazy - wizualne reprezentacje życia we „wspólnym pokoju”.

\section{Przestrzeń liminalności}

$\mathrm{Z}$ analiz przeprowadzonych przez Miłosławę Borzyszkowską-Szewczyk wynika, że miejskie modi co-vivendi zależne są z jednej strony od społeczno-politycznego kontekstu życia miasta; z drugiej - od charakteru jednostkowych mikroświatów, które formują relacje i które Badaczka rozpoznaje za pomocą analizy dwóch autobiograficznych narracji mieszkańców przedwojennego Gdańska o żydowskim pochodzeniu. Badanie przynosi w rezultacie niezwykły opis bramy jako przestrzeni ciągle dokonujących się wyborów i codziennego formułowania znaczeń co-vivendi. Można powiedzieć, że w badaniach Borzyszkowskiej-Szewczyk brama jest testem dla modus co-vivendi, nieustannie wystawiając je na próbę. Jak każde miejsce przejścia, każdy próg, brama zawiesza istniejący porządek. W odniesieniu do miejskiego współżycia podważa status quo każdej z jego wersji, zmaterializowanych w jej przestrzeni jako wyraz - dopiero w niej ujawniających się - podziałów, konfliktów, napięć. Brama zawsze $\mathrm{w}$ jakiś sposób sobie $\mathrm{z}$ nimi radzi (rozszczepia je na wielorakie znaczenia, przenosi do sfery symbolicznej, uświęca, zapowiada zmianę itd.), pełniąc liminalne funkcje w miejskiej przestrzeni. Jest zatem również pytaniem o nowe modi, nieznany jeszcze kształt co-vivendi, jaki wyłoni się po jej opuszczeniu.

Opis dokonany przez Autorkę, stając się uogólnieniem doświadczenia, uniwersalizuje bramę i pozwala tym samym myśleć o niej jak o pojemnej kategorii teoretycznej. Między innymi zbiera ona wyrazy aktualnie przeżywanego kryzysu humanitarnego (Autorka trafnie zauważa, jak polaryzuje się to w dyskursie wokół problemu „uchodźców u bram” czy „bram do lepszego świata”). Nierozstrzygniętą jednak kwestią pozostaje, w jakim zakresie walory eksplanacyjne i prospektywne koncepcji budowanych z wykorzystaniem tej kategorii, otworzą współczesne miasta na owocne rozwiązania tego - najgorętszego dzisiaj - problemu społecznego w Europie. Tak czy inaczej, myśl Autorki o gdańskich modi co-vivendi, zawartych $\mathrm{w}$ analizowanych narracjach, stwarza niewątpliwie przyczynek do jego rozwiązywania na co dzień, w miejskim życiu i rosnących na edukacyjnej pożywce, międzykulturowych kompetencjach mieszkańców miast. 


\section{Przestrzeń współdzielonej traumy}

Katarzyna Stankiewicz, Alicja Zbierzchowska i Sylwia Bykowska w biograficznych narracjach przesiedleńców ze Wschodu dostrzegają, że gdańskie modi co-vivendi kształtowały się z udziałem nowo po II wojnie przybyłych mieszkańców, dosłownie, od pierwszych chwil spędzanych przez nich w mieście. Ich „układanie” się w jego społecznej i fizycznej przestrzeni to pełne przeżytego bólu wygnania, empatyczne wobec wypędzanych z Gdańska Niemców tworzenie wspólnoty traumatycznego doświadczenia. Szczególną wartość w niej stanowiło zaufanie, budujące się na kryterium doświadczonych przeżyć. Stąd wspólnoty te formowały się często pomiędzy nimi i mieszkańcami Gdańska niemieckiego pochodzenia, z czasem "znikającymi sąsiadami”. Autorki dokumentują kształtowanie się powojennych modi co-vivendi Gdańska, dokonujące się z tkwiącą w Kresowianach silną potrzebą „udzielania” się, nazywaną znacząco w perspektywie idei „wspólnego pokoju” i miejskich wzorów co-vivendi jako - oparte na wzajemnej wrażliwości na potrzeby - sposoby podzielania przestrzeni miasta. Potrzeba ta była tym bardziej wyrazista, im dotkliwsze było odczuwanie braku jej spełniania w otoczeniu nieopisywanym jako przyjazne. Narratorzy, z trudem w tych warunkach wypracowując podstawy (z)godnego współżycia w mieście, edukacyjnie konstruowali znaczenie praktyk określanych jako „udzielanie” się (zorientowane między innymi na legitymizację statusu gdańszczanina), ucząc się go w pełnej wyzwań codzienności. Na podstawie badania opowieści Kresowian o ich powojniu w Gdańsku można skonceptualizować gdańskie modi co-vivendi jako wzory powstające na zaufaniu kształtującym więzi i skutkującym powstawaniem wspólnot opartych na jednoczącym doświadczeniu. Podstawowym spoiwem dla tak rozumianego budulca co-vivendi jest silny imperatyw społecznego udzielania się - podzielania siebie w działaniach, korzystnie dla siebie i innych przekształcającego zarówno społeczną, jak i materialną przestrzeń miasta.

Autorki puentują postulatem przeniesienia organizacji miejskiej edukacji w tym zakresie na poziom małych lokalnych wspólnot (dzielnicowych, sąsiedzkich), w nich widząc najbardziej obiecujący potencjał w wypracowywaniu aktualnych postaci co-vivendi.

\section{Przestrzeń terapeutyczna}

Agnieszka Bzymek natomiast, podążając tropami miejskich modi co-vivendi, prowadzi do „wnętrza miasta”, przeprowadzając jego psychoanalizę. Ten badawczy zabieg pozwala ostatecznie na opis współczesnych gdańskich postaci co-vivendi, wiążących się $\mathrm{z}$ akcentowanym przez Autorkę "poczuciem miejsca” i samopoznaniem towarzyszącym ich wytwarzaniu. Jej fenomenograficzne badanie, przeprowadzone 
wśród osób odwiedzających gdańskie galerie sztuki, prowadzi do rekonstrukcji fenomenu terapii mieszkańców, dokonującej się z terapeutycznym oddziaływaniem miasta przez miejsca wypełnione sztuką.

Tłem dla tego rodzaju poszukiwań jest aktualnie odnotowywana w przestrzeni miejskiej dominacja „kultury terapeutycznej” (w terminologii Małgorzaty Jacyno). Żyjąc w konsumpcyjnej rzeczywistości nieustannej rywalizacji i niepewności, mieszkańcy współczesnych miast znajdują dla siebie terapię w autokreacji, akcentującej ich indywidualność i podmiotowość. Terapia ta jednak opiera się na tym samym modelu, według którego funkcjonuje społeczeństwo konsumpcyjne. Rządzą nią konsumenckie wybory. W tym świetle tożsamość to wynik selekcji, bo ja powstaje $\mathrm{z}$ dowolnie wybranych składników, a nie z zasobów, jakie stanowi tradycja rodzinna, historia itd. Odwiedzanie miejskich galerii natomiast to $\mathrm{z}$ jednej strony wyraz poszukiwania elementów do kontynuacji układanki, jaką stanowi tożsamość mieszkańca; z drugiej, ze względu na - polaryzujący jednostkowe doznania - charakter relacji ze sztuką, jest to przejaw oporu wobec męczącej, na co dzień w mieście doświadczanej masowości konsumpcji. Bzymek przedstawia wyniki swoich badań jako rozmaite postaci terapeutycznego zaspokajania przez kontakt z miejscami sztuki różnorodnych miejskich „głodów”, między innymi głodu społecznych relacji, który - w kontekście pozostałych - konceptualizowany jest przez badanych w sposób definiujący zarówno ideały, jak i praktyki w zakresie form wzajemnie akceptowanego, godnego współzamieszkiwania miasta jak wspólnego pokoju. Użytkownicy gdańskich galerii opisują i współtworzą miejskie modi co-vivendi, wypełniając dotkliwie odczuwane deficyty miłości, poczucia wartości i godności, wiedzy, sztuki, a nade wszystko tworzenia relacji społecznych i bycia $\mathrm{z}$ drugim człowiekiem, jak przekonuje Bzymek.

\section{Przestrzeń twórczości}

Badania Doroty Grubby-Thiede nad miejskimi modi co-vivendi to - jak pisze badaczka za Witosławem Czerwonką - „dotykanie spraw ledwie przeczutych”. W tym zapożyczeniu, odsyłającym do pedagogicznego credo jednego z najwybitniejszych nauczycieli, profesora gdańskiej Akademii Sztuk Pięknych, tkwi istota myślenia Autorki o wzajemnie dobrym współzamieszkiwaniu miasta. Sformułowaniem tym uwypuklony zostaje edukacyjny charakter różnych postaci akceptowanego wzajemnie współzamieszkiwania miasta, w których kształtowaniu najważniejsze wydaje się zawsze pełne delikatności, wrażliwe uczenie się siebie wśród innych i innych w sobie jednocześnie. Jak przekonują analizy wybranych prac trójmiejskich artystów w otwartej, społecznej przestrzeni metropolii, twórczość nie tyle dla ludzi, co z nimi, odgrywa w tym kluczową rolę. „Sprawy ledwie przeczute”, których badaczka subtelnie „dotyka” swoimi analizami na podstawie wielu przywołanych 
projektów artystycznych, to między innymi nieodwracalność zmian ludzi i miejsc, przemijanie jednych i drugich. W tym świetle modi co-vivendi są, wypracowanymi z pomocą sztuki, sposobami radzenia sobie z tym, co nie do końca wiadome; z ignorancją, która przytłacza, ale też uwalnia pokłady poznawczej aktywności i pozwala na tworzenie w mieście „miejsc energetycznych”, z powodzeniem rozsiewających owe modi.

\section{Zakończenie}

Przedstawione przestrzenie lokalnej demokracji można widzieć jak hologram, w którego każdym elemencie reprezentowana jest całość, czyli demokratyczne miasto. Przykłady te pokazują jak Rancièrowskie, radykalne założenie równości, wyrażone w metaforze wspólnego pokoju, jest produktywne na poziomie mikrorelacji zawiązywanych w fizycznych miejscach miasta, dla których znaczący kontekst stanowi urbanistyczna ich kompozycja: miasto, jak Arystotelesowska polis - wielka nauczycielka cnoty - wspólnota wspólnot i z wszystkich nich najważniejsza, bo godząca w akceptowalnej przez wszystkich mieszkańców cnocie to, co poszczególnym wspólnotom składowym cnotą się wydaje ${ }^{34}$.

Ważne, by miasto - jakkolwiek wprzęgane dzisiaj w globalne interesy - nie traciło tej swojej funkcji i było nakierowaną na człowieka nauczycielką tego, co dobre dla wszystkich i zarazem dla każdego; by uczyło co-vivendi, tworząc tak swoją demokratyczną codzienność.

Przywołane badania i sporządzony na ich podstawie opis rozmaitych przestrzeni demokracji lokalnej potwierdzają istotność obywatelstwa w jego mikroświatach, sąsiedzkich, małych społecznościach. Wspomniane zainteresowanie współczesnego człowieka najbliższą mu sferą lokalną znalazło wyraz w praktykowaniu demokratycznych postaci współżycia, które jest współzamieszkiwaniem miasta. Okazuje się, że przestrzeń wspólna, należąc do nas wszystkich - jest moja i zarazem twoja, i jeszcze twoja - nasza w sensie otwartej koniunkcji, a nie alternatywy (albo - albo). Taka wspólna przestrzeń publiczna to coś więcej niż suma tworzących ją, wchodzących w relacje ludzi. Po pierwsze, relacje te gdzieś zachodzą i zarówno dla ich kształtu, jak i rezultatów znaczące jest miejsce, w którym to się dzieje. Miejsce, konkretne tu, ma wymiar materialny, przez który bierze udział w tworzeniu wspólnej przestrzeni. Wypełniające ją relacje bez miejsca nie mogą się obyć, a ono nie pozostaje wobec

${ }^{34}$ Jak pisał: „każda wspólnota powstaje dla osiągnięcia jakiegoś dobra (wszyscy bowiem w każdym działaniu powodują się tym, co im się dobrem wydaje), to jasną jest rzeczą, że wprawdzie wszystkie [wspólnoty] dążą do pewnego dobra, lecz przede wszystkim czyni to najprzedniejsza ze wszystkich, która ma najważniejsze ze wszystkich zadanie i wszystkie inne obejmuje". Arystoteles, Polityka, przekł. L. Piotrowicz, Warszawa 2004, 1252 a. 
nich obojętne. To, jakie miejsce jest, ma znaczenie dla naszej kondycji bycia razem, czasem wprost umożliwia ją lub blokuje. Spróbujmy budować między sobą związek, kiedy każdy do każdego siedzi tyłem, bo inaczej nie da się w tym miejscu z takimi krzesłami itp. Po drugie, przestrzeń publiczna, którą tworzymy razem, zawiera synergiczny element „pomiędzy” - coś, co powstaje między nami i w czym swój udział ma charakter miejsca, w którym zachodzi nasza relacja. Chodzi o ekstra jakość, przestrzennie wytwarzaną w naszych siedliskach, wsiach, miastach i miasteczkach. Badacze tego fenomenu od lat wiążą go $\mathrm{z}$ demokracją, głosząc - jak socjolog miasta, Louis Wirth w latach 30. XX wieku ${ }^{35}$, czy filozof polityki, Pierre Rosanvallon w początkach wieku XXI ${ }^{36}$ - że chodzi o wspólność; styl i jakość życia, nierozerwalnie związaną z jego miejscem. Wspólność polega na wielozmysłowym, wzajemnym dostrzeganiu się, choćby kątem oka; nieustannym 'ocieraniu się o siebie jako przechodnie czy sąsiedzi. Wspólność na takich nieprzerwanych lekcjach (z) siebie polega i z nich też wynika. Bez tak nasyconej edukacyjnie wspólności, która jest okazją zarówno do artykulacji własnych, jak i zauważania czyichś potrzeb, nie ma demokratycznego współistnienia. To wspólność wytwarzana tam, gdzie żyjemy razem, jest tym, co wyrasta ponad sumę nas, jej współtwórców. Jako taka jest naszym lokalnym, sąsiedzkim dobrem; w określonych warunkach osiągniętym i podzielanym wzajemnie dobrem publicznym.

Jest ono bardzo kruche, jak kruche w swojej zmienności są nasze relacje. Sąsiedzką wspólność - na przykład - rozpoznamy doskonale, kiedy nie będziemy mieli wątpliwości, że tu, wśród tych ludzi i domów, na tej ulicy czy podwórku albo klatce schodowej możemy swobodnie żyć, co oznacza móc działać i czuć, że możemy być wolni (tak widzi to Gert Biesta ${ }^{37}$ ). Wystarczy jednak zgrzyt - np. wyrośnie płot tam, gdzie prowadziła ścieżka naszego skrótu w drodze do sklepu, albo zamiast zwykle spokojnych tonów rozmów słyszalnych zza ściany, zaczniemy słyszeć jazgot kłótni - akceptowana zmysłami i odczuwana jako pełna sensu przestrzeń naszej wspólności przestaje istnieć, a kruche dobro, jakim była, znika. Demokratyczność wiązana ze wspólnością zasadza się jednak właśnie na tej kruchości. Jest demokratycznie (podmiotowo, równościowo) i dobrze nam tam, gdzie właściwie nieustannie układamy się pomiędzy sobą, a łamiące estetyczną harmonię naszego życia zgrzyty traktujemy jak sygnały, przez pryzmat których widać, słychać i czuć potrzeby innych, oraz dzięki którym identyfikujemy własne. Nie identyczność, a różnica; nie wiekuista zgoda, lecz przeżywane na co dzień starcia czynią wspólność żywym, aktywnie kultywowanym dobrem publicznym.

${ }^{35}$ L. Wirth, Urbanism as a Way of Life, "American Journal of Sociology” 1938, vol. 44, nr 1, s. $1-24$.

36 P. Rosanvallon, Wspólność, przekł. B. Jastrzębski, „Res Publica Nova” 2016, nr 2, s. 27-33.

${ }^{37}$ G.J.J. Biesta, Becoming Public: Public Pedagogy, Citizenship and the Public Sphere, „Social and Cultural Geography" 2012, 13 (7), s. 683-697. 


\section{Bibliografia}

Arystoteles, Polityka, przekł. L. Piotrowicz, Warszawa 2004.

Augé M., Nie-miejsca. Wprowadzenie do antropologii hipernowoczesności, przekł. R. Chymkowski, Warszawa 2010.

Bauman Z., Płynna nowoczesność, przekł. T. Kunz, Kraków 2006.

Bauman Z., Płynne życie, przekł. T. Kunz, Kraków 2007.

Bauman Z., Collateral Damage. Social Inequalities in a Global Age, Cambridge-Malden 2011.

Bauman Z., O edukacji, przekł. P. Poniatowska, Wrocław 2012.

Beck U., Giddens A., Lash S., Modernizacja refleksyjna, przekł. J. Konieczny, Warszawa 2009.

Biesta G.J.J., Becoming Public: Public Pedagogy, Citizenship and the Public Sphere, „Social and Cultural

Geography" 2012, 13 (7), s. 683-697.

Butler J., Zapiski o performatywnej teorii zgromadzeń, przekł. J. Bednarek, Warszawa 2016.

Certeau de M., Wynaleźć codzienność. Sztuki działania, przekł. K. Thiel-Jańczuk, Kraków 2008.

Harvey D., Bunt miast. Prawo do miasta i miejska rewolucja, Warszawa 2012.

Heidegger M., Bycie i czas, przekł. B. Baran, Warszawa 2013.

Kawula S., Pedagogika społeczna w koncepcji społeczeństwa ryzyka, „Kultura i Edukacja” 2005, nr 4, s. $32-42$.

Kawula S., Pedagogika społeczna w początkach XXI wieku - perspektywa koncepcji społeczeństwa ry$z y k a$, „Chowanna” 2003, nr 2, s. 25-43.

Krastev: Walka o przejrzystość zabija demokrację, http://www.krytykapolityczna.pl/artykuly/ ue/20130331/krastev-walka-o-przejrzystosc-zabija-demokracje [dostęp: 2.05.2021].

Massey D., Space, Place and Gender, Cambridge 1994.

Mendel M., Pedagogika miejsca wspólnego. Miasto i szkoła, Gdańsk 2017.

Mendel M., Wspólny Pokój Gdańsk. Miejskie „modi co-vivendi” w badaniu metodą Krytycznej Historii Miasta, [w:] eadem (red.), Miasto jak wspólny pokój. Gdańskie modi co-vivendi, Gdańsk 2015.

Mendel M. (red.), Miasto jak wspólny pokój. Gdańskie modi co-vivendi, Gdańsk 2015.

Mendel M., Skrzypczak B. (red.), Praca socjalna jako edukacja ku zmianie, Warszawa 2013.

Mouffe C., Paradoks demokracji, przekł. W. Jach, M. Kamińska, A. Orzechowski, Wrocław 2005.

Radlińska H., Pedagogika społeczna, Warszawa 1961.

Rancière J., Dzielenie postrzegalnego. Estetyka i polityka, przekł. M. Kropiwnicki, J. Sowa, wstęp M. Pustoła, słownik zestawił K. Mikurda, Kraków 2007.

Rosanvallon P., Wspólność, przekł. B. Jastrzębski, „Res Publica Nova” 2016, nr 2, s. 27-33.

Sassen S., Globalizacja. Eseje o nowej mobilności ludzi i pieniędzy, przedmowa K.A. Appiah, przekł. J. Tegnerowicz, Kraków 2007.

Szkudlarek T., Miejsce, przemieszczenie, tożsamość, [w:] J.P. Hudzik, J. Mizińska (red.), Pamięć, miejsce, obecność. Wspótczesne refleksje nad kultura i ich implikacje pedagogiczne, Lublin 1997.

Tuan Y.-F., Przestrzeń i miejsce, przekł. A. Morawińska, Warszawa 1987.

Vattimo G., Społeczeństwo przejrzyste, przekł. M. Kamińska, Wrocław 2006.

Wirth L., Urbanism as a Way of Life, „American Journal of Sociology” 1938, vol. 44, nr 1, s. 1-24. 